\title{
PENGATURAN KESELAMATAN DAN KEAMANAN PELAYARAN DI INDONESIA
}

\author{
A.A. Ayu Diali UthariPramesti, I Ketut KastaArya Wijaya \& Desak GdeArini \\ Fakultas Ilmu Hukum, Universitas Warmadewa, Denpasar-Bali, Indonesia \\ ayudiah616@gmail.com, kastaaryawijaya@gmail.com \&arinidesak1966@gmail.com
}

\begin{abstract}
Abstrak
Negara Indonesia adalah negara maritim yang dikelilingi oleh laut yang kaya akan sumber daya alam, oleh karenanya dibutuhkan sistem kesatuan untuk menjaga keamanan dan juga untuk mengalokasikan segala sumber energi yang ditawarkan oleh laut agar dapat dikelola dengan tepat. Pengelolaan keselamatan serta keamanan perairan di Indonesia diatur dalam undang-undang Nomor 17 Tahun 2008 tentang Pelayaran. Penelitian ini bertujuan untuk mengkaji peraturan mengenai persyaratan keselamatan serta keamanan di wilayah perairan Indonesia dan untuk menganalisis kewenangan pemerintah daerah dalam pembinaan terhadap persyaratan keselamatan dan keamanan pelayaran di wilayah perairan Indonesia. Penelitian ini adalah penelitian hukum normatif, dengan menggunakan pendekatan peraturan perundang-undangan serta pendekatan konseptual. Hasil dari penelitian ini adalah pengaturan pembinaan-pembinaan pelayaran dilaksanakan oleh pemerintah. Bentuk pembinaan yang dilakukan oleh pemerintah berupa pengawasan, pengendalian, serta pengaturan. Perlindungan hukum penyelenggaraan otonomi daerah sejalan dengan ketentuan Undang-Undang Nomor 23 Tahun 2014 yang melibatkan pemerintah daerah dan melaksanakan perlindungan hukum atas berbagai urusan pemerintahan dalam rangka pengabdian masyarakat serta pengelolaan sumber daya alam.
\end{abstract}

Kata Kunci: Keamanan, Pelayaran, Perairan Indonesia, Pengaturan, Keselamatan.

\begin{abstract}
Indonesia is a maritime country surrounded by a sea that is rich in natural resources, therefore a unified system is needed to maintain security and also to allocate all energy sources offered by the sea so that it can be managed appropriately. The management of water safety and security in Indonesia is regulated in Law Number 17 of 2008 concerning Shipping. This research aims to analyze the regulations about the official procedure of safety in Indonesian territorial waters and to analyze the government's authority to fostering safety and security requirements for shipping in Indonesian territorial waters. This research is a normative legal research, using a statutory approach and a conceptual approach. The result of this research is the management of shipping coaching is carried out by the government. The form of guidance carried out by the government is in the form of supervision, control and regulation. Legal protection for the administration of regional autonomy is in line with the provisions of Law Number 23 o/2014 which involves regional governments and carries out legal protection for various government affairs in the context of community service and natural resource management.
\end{abstract}

Keywords: Indonesian maritime territory, Regulation, Safety, Security, Shipping.

\section{PENDAHULUAN}

Sebagai satu kesatuan kehidupan di nusantara, Indonesia dikelilingi oleh laut, dan transportasi laut memainkan peran strategis yang signifikan dalam pengetahuan, perdagangan, dan keamanan nasional nusantara. Dengan melihat fakta yang ada di wilayah Indonesia, agar dapat mendukung terwujudnya wawasan nusantara perlu diupayakan pemanfaatan perairan lndonesia dengan baik. Pemanfaatan laut oleh bangsa Indonesia sangat penting dilakukan guna menjaga kelangsungan hidup serta membangun kehidupan bernegara. Maka dari itu Indonesia membutuhkan tenaga laut yang dicirikan sebagai keahlian suatu bangsa didalam mengalokasikan segala sumber energi serta peluang yang ditawarkan oleh laut untuk memenuhi kebutuhan warganya serta menggunakan 
kekuatan laut (Roesli, 1988: 160-162). Secara universal, tiga konsep fundamental masih diterapkan di negara manapun yang menganut rule of law. Perlakuan adil dibawah hukum merupakan konsep sentral dari kerangka negara hukum. Ide yang mendasari keadilan merupakan konsep prosedural due process of law (Munir, 2009: 47). Indonesia dikenal sebagai negara maritim yang menjunjung tinggi regulasi pelayaran nasional. Tujuan aturan ini adalah untuk menjamin keamanan dan stabilitas kekuasaan negara. Undang-undang tentang Transportasi memiliki tujuan dengan memprioritaskan dan melindungi transportasi di perairan dari pergeseran manusia atau benda di maritim untuk mempercepat kegiatan ekonomi negara, membangun jiwa kebaharian, mengembangkan industri transportasi perairan nasional dengan menjaga kedaulatan nasional dan membangun daya saing, mendukung, mendorong dan mengajak terwujudnya pembangunan nasional yang bermaksud dalam rangka mewujudkan persatuan dan kesatuan negara keilmuan nusantara serta memajukan pertahanan negara (Djohan, 2008).

Tujuan pelayaran dapat ditentukan secara jelas berdasarkan tujuan pelayaran, yang meliputi membagikan proteksi pertahanan serta keamanan untuk negara dan masyarakat, serta mengembangkan ekonomi negara. Syarat Undang-undang Nomor 17 Tahun 2008 tentang Pelayaran bisa diperluas untuk semua operasi transportasi laut, pelabuhan, serta keselamatan serta perlindungan pelayaran, dan pelestarian lingkungan laut Indonesia. Lebih lanjut, dilihat dari undang-undang ini memberikan perlindungan bukan saja hanya diinternal perairan Indonesia, tapi termasuk eksternal perairan Indonesia untuk seluruh kapal berisikan bendera Indonesia. Undangundang ini mengacu pada setiap kapal luar negara Indonesia yang tidak berisikan bendera Indonesia berlayar di wilayah maritim Indonesia dengan bendera asing. Di wilayah maritim Indonesia, negara memiliki kendali penuh atas perkapalan, serta pelaksanaan negara dilaksanakan oleh pemerintah terhadap pembinaan serta juga pelaksanaan negara. Regulasi, pemantauan, dan pengawasan adalah mekanisme yang digunakan pemerintah untuk memberikan pedoman keselamatan dan keamanan diatur dan diawasi pelayaran melalui navigasi untuk menunjang keselamatan dan keamanan pelayaran dimana pemerintah telah membentuk fasilitas navigasi agar pelayaran dapat beroperasi dengan lancar dan aman. Meski sudah ada tindakan perlindungan keselamatan di perairan, namun penerapan tindakan perlindungan keselamatan masih belum cukup, seperti penerbitan sertifikat transportasi kapal dan sertifikat kelayakan transportasi kapal yang belum sepenuhnya diperiksa. Jika kapal tidak diinspeksi secara menyeluruh maka keselamatan yang dibutuhkan akan berkurang dan akan menimbulkan bahaya serta menimbulkan korban pada suatu waktu.

Penelitian terdahulu yang relevan dengan penelitian ini adalah yang mengkaji mengenai kewenangan pemerintah terhadap keselamatan dan keamanan perairan Indonesia (Hamdi, 2016), dimana penelitian ini menjelaskan pemerintah berwenang dalam mengeluarkan aturan pelayaran yang bertujuan untuk menajaga keselamatan dan keamanan bagi warga negara. Penelitian selanjutnya membahas mengenai rendahnya manejemen keselamatan pelayaran pada perairan alur laut kepulauan Indonesia (ALKI) II dan III (Kadarisman, 2017). Menurut Hutagalung (2017) bahwa penetapan alur laut kepulauan indonesia sangat penting dalam keamanan pelayaran, Hutagalung juga menjelaskan manfaat penetapan alur laut dan ancaman bagi keamanan pelayaran diwilayah perairan Indonesia. Jadi, penelitian ini bertujuan untuk mengkaji pengaturan keselamatan dan keamanan pelayaran di Indonesia serta upaya-upaya apa yang dilakukan untuk mewujudkan keamanan yang diidamkan.

Berdasarkan dari pada uraian yang dipaparkan sebelumnya, Penelitian ini bertujuan untuk mengkaji peraturan mengenai persyaratan keselamatan serta keamanan di wilayah perairan Indonesia dan untuk menganalisis kewenangan pemerintah daerah dalam pembinaan terhadap persyaratan keselamatan dan keamanan pelayaran di wilayah perairan Indonesia.

\section{METODE PENELITIAN}

Penelitian ini menggunakan proses pendalaman hukum normatif. Penelitian normatif adalah penelitian yang diperoleh dari penjelasan secara detail dan sistematis dengan cara membedah aturan hukum (Susanti \& effendi, 2014). Penelitian ini menggunakan pendekatan konseptual dan pendekatan perundang-undangan, karena peneliti menggunakan perundang-undangan sebagai 
bahan review dan analisa mengenai penyelesaian masalah dari aspek konsep-konsep hukum yang terkandung didalamnya. Pendekatan konseptual adalah pendekatan yang merupakan penyimpangan dari pandangan dan doktrin ilmu hukum. Pendekatan perundang-undang disini digunakan atas dasar kepada pengaturan perundang-undangan, serta norma hukum yang sangat berhubungan dengan Pengaturan Pembinaan Keselamatan dan Keamanan Pelayaran di Perairan Indonesia.

\section{PEMBAHASAN}

\section{Pengaturan Pembinaan Terhadap Persyaratan Keselamatan Dan Keamanandi Wilayah} Perairan Indonesia

Empat unsur utama pelayaran yakni transportasi air, keamanan keselamatan pelayaaran, pelabuhan, dan melindungi wilayah laut yang dimuat di dalam Undang-undang tentang Pelayaran yang apabila diuraikan adalah sebagai berikut:

a. Ketentuan pada sektor bagian perhubungan di wilayah maritim atau laut antara lain meliputi asas pelaksanaan (asas cabotage) dimana pemberian kewenangan transportasi laut nasional yang menciptakan lingkungan mendukung bagi kemajuan transportasi laut, termasuk kemudahan pelayanan sarana dibidang perhubungan laut. perpajakan, serta keberadaan modal dalam pengadaan kapal serta ketersediaan sumber daya dalam pembelian kapal, dan sifat kontrak transportasi air jangka panjang.

b. Penghapusan monopoli didalam administrasi pelabuhan, pembagian tugas antara regulator dan kontraktor dan keterlibatan pemerintah lokal serta sektor swasta dalam operasi pelabuhan juga tercakup dalam peraturan pelabuhan.

c. Ketentuan pengaturan dibidang pengamanan keselamatan transportasi laut mengandung atau menampung ketentuan peraturan yang mencegah majunya teknologi dengan bertumpu kepada klausul yang lebih mengarah kepada penggunaan perangkat masa kini didalam pemanfaatan fasilitas serta infrastruktur keamanan, kedamaian serta juga ketentraman transportasi laut. Selain kemudahan akomodasi fasilitas pengaturan mengenai bentuk keamanan transportasi laut.

d. Ketentuan didalam sektor penjagaan, pemeliharaan, pelestarian, pengawasan wilayah laut atau memberikan aturan untuk mitigasi serta pemantauan degradasi wilayah air dimana pengendaraan transportasi air serta fasilitas serupa yang berupa kemudahan aturan internasional yang berhubungan (Sembiring, 2009).

Sebagaimana ditetapkan dalam Undang-undang tentang Pelayaran bahwa pelayaran dimiliki, dikuasai atau dikendalikan oleh pemerintah Indonesia dimana pemerintah Indonesia memiliki wewenang atau hak kekuasaan terhadap pelaksanaan, pemanfaatan, pengelola, penggarap, pengurus dan pembuat pelayaran dimana pelaksanaannya mencakup bagian ketentuan, penanganan, penanggulangan, pengawalan, pengelolaan, pengoperasian, pengendalian, dan penjagaan. Pembinaan pelayaran dilaksanakan oleh pemerintah. Pelayaran merupakan kerangka kerja terpadu yang mencakup transportasi air, keselamatan dan keamanan, pelabuhan, dan pengawasan wilayah perairan. Alhasil, undang-undang tidak hanya memuat pengaturan tentang aspek dasar pelayaran, tetapi pada dasarnya juga memuat pengaturan pada seluruh aspek pelayaran, yaitu navigasi, pelabuhan, transportasi, tabrakan kapal, SAR, dan lain sebagainya. Ketentuan mengenai pembinaan, sumber daya manusia, investigasi serta ketentuan pidana (Umar, 2001). Selain itu untuk menjamin keselamatan dan keamanan dalam pelayaran pemerintah melakukan perencanaan, pengadaan, pengoperasian, pemeliharaan, dan pengawasan sarana bantu navigasi pelayaran dan telekomunikasi pelayaran sesuai dengan ketentuan internasional, serta menetapkan alur pelayaran dan perairan serta menetapkan zona keamanan dan keselamatan (Hamdi, 2016).

Sebagai negara maritim, Indonesia menjunjung tinggi regulasi pelayaran nasional yang dirumuskan untuk mengamankan dan menstabilkan pengamanan negara. Undang-undang tentang Pelayaran memiliki tujuan dengan memprioritaskan serta juga melindungi, menjaga, merawat transportasi di perairan dari pergeseran di laut untuk mempercepat kegiatan ekonomi negara, membangun jiwa kebaharian, mengembangkan industri transportasi perairan nasional dengan 
menjaga kedaulatan nasional dan membangun daya saing, mendukung, mendorong dan mengajak terwujudnya tujuan pembangunan negara dan memperkuat bangsa untuk mewujudkan memajukan pertahanan negara. Syahbandar merupakan pejabat pemerintah yang menjalankan tugas pengamanan keselamatan pelayaran. Dalam menjalankan tugas pengamanan keselamatan pelayaran yang berupa penyelenggaraan, pengawasan, penegakkan hukum dibidang transportasi air, pelabuhan, serta perlindungan wilayah laut di pelabuhan.

\section{Kewenangan pemerintah daerah dalam pembinaan terhadap persyaratan keselamatan dan keamanan pelayaran di Wilayah Perairan Indonesia}

Kewajiban dan tanggung jawab adalah dua kata yang digunakan dalam kamus hukum untuk menggambarkan tanggung jawab. Kewajiban berlaku untuk bertanggung jawab, adalah suatu sikap karena ditimbulkan dari kelalaian, sedangkan kewajiban yang bertanggung jawab merupakan suatu perilaku apabila perilaku tersebut illegal atau terlarang, maka dapat dikenakan sanksi atau hukuman. Tanggung jawab diartikan sebagai rasa yang dimiliki oleh seseorang karena ditekankan atau difokuskan kepada arti yang timbul dari aturan yang berlaku (Ridwan, 2006: 337).

Ketika seseorang atau orang secara hukum bertanggung jawab atas tindakan atau perilaku tertentu, itu adalah istilah yang berkaitan dengan kewajiban moral orang tersebut untuk menghukum perilaku tersebut jika itu ilegal. Dalam penyelenggaraan negara dan pemerintahan sistem pertanggungjawaban ini termasuk kedalam sebuah kedudukan yang berkaitan langsung dengan kewenangan dalam penyelenggaraan negara dan pemerintahan. Kata dasar kewenangan pada umumnya bersumber dari istilah kedaulatan, kekuasaan, otoritas, kuasa, wewenang, serta kekuatan yang artinya sesuatu yang bertugas, bertanggung jawab, memiliki hak dan kuasa untuk melakukan atau melaksanakan sebuah tindakan. lstilah kekuasaan, kedaulatan mengacu pada kontrol formal yang berasal dari kekuasaan legislatif atau eksekutif administratif. Kontrol atas sekelompok warga negara atau kekuasaan atas wilayah pemerintahan tertentu adalah kekuasaan, yang biasanya terdiri dari berbagai bentuk pemerintahan (Atmosudirdjo, 1981). Kewenangan merupakan kekuatan untuk membentuk keputusan yang mengatur serta memberikan tanggung jawab terhadap orang lain. Kewenangan tersebut adalah kekuatan yang diresmikan terhadap orang khusus atau kekuasaan atas wilayah pemerintahan khusus yang bersumber dari kekuasaan legislatif atau pemerintah (Nono, et.al. 2020: 140).

Wilayah kepulauan Indonesia secara geografis terletak di kawasan tropis yang berada diantara dua benua, dua samudra, dan pertemuan tiga lempeng utama dunia, mengakibatkan melimpahnya SDA laut yang begitu melimpah yaitu seperti SDA biotik maupun abiotik, serta fasilitas pelayanan terhadap lingkungan. Akibatnya, Indonesia luar biasa karena memiliki jutaan SDA yang dapat dimanfaatkan, digunakan, diproduksi, dan diolah di masa depan demi kebaikan bangsa dan keturunannya. Indonesia adalah pulau maritim yang dikelilingi perairan, maka penting agar pengiriman, penyampaian benda antar pulau menggunakan atau memanfaatkan pelayaran. Pelayaran begitu berarti untuk masyarakat karena dapat membuat mereka satu sama lain saling terkait dengan memungkinkan mereka untuk berlayar. Alhasil, Indonesia kaya dengan keanekaragaman budaya di samping sumber daya alamnya (Djohan, 2008).

Undang-Undang Nomor 23 Tahun 2014 tentang Pemerintahan Daerah diciptakan dari sudut pandang bahwa NKRl mempunyai kepulauan yang begitu sangat luas serta lautan yang lebih luas melebihi daratan, sangat tidak mungkin bisa dikelola dengan baik tanpa adanya pemerataan tugas kewajiban diantara Pemerintah Pusat serta Pemerintah Daerah di tengah penyelenggaraan pemerintahan, yang meliputi penyelenggaraan wilayah laut. Dengan adanya letak Indonesia di sela-sela perairan samudera maka dari itu penyerahan kewenangan antara pemerintah pusat serta pemerintah daerah didalam penyelenggaraan laut, atau penyelenggaraan wilayah laut oleh pemerintah pusat serta pemerintah daerah merupakan suatu kemampuan yang bisa digunakan melalui prinsip berbagi tanggung jawab. Dalam rangka pengelolaan dan pemanfaatan laut, baik secara spasial maupun dari segi sumber daya alam dan letak yang strategis, Pemerintah Pusat serta pemerintah daerah wajib bisa memanfaatkan kekayaan laut dengan didukung oleh teknologi, ilmu pengetahuan, peralatan, serta kemampuan lainnya. 
Peran pelaksanaan pemisahan tugas pengelolaan wilayah laut serta wilayah maritim telah ditujukan agar terbagi antara otoritas nasional dan daerah agar proses pemungutan keputusan lebih dekat dengan masyarakat di lapangan, dengan memperhatikan faktor karakteristik adat serta daerah, sampai keputusan umum, masyarakat, khalayak banyak bisa sangat dimasukkan serta mampu menghasilkan serta aktif dalam pemenuhan kebutuhan dan rasa keadilan kepada masyarakat. Pemisahan pengelolaan antara kekuasaan pusat serta daerah didalam manajemen, penyelenggaraan, pemanfaatan, serta pengurusan wilayah perairan, terutama kekuasaan pemerintah pusat untuk wilayah perairan, bertujuan agar bisa meningkatkan serta menambahkan kecakapan, kemahiran, kinerja, keterampilan, potensi, serta keahlian penjagaan perairan, terutama pada kawasan tapal baras. Meningkatkan kualitas hidup penduduk di semua wilayah perbatasan negara Indonesia dengan menerapkan berbagai langkah yang berhasil dan kegiatan untuk pertumbuhan jangka panjang yang inklusif yang dibangun diatas kapasitas modal lokal, sejarah, dan aspek penjualan.

Pemisahan pengelolaan kelautan serta maritim antara kewenangan pusat dan daerah bertujuan agar proses pemungutan keputusan dengan masyarakat di lapangan dengan memperhatikan karakteristik kebudayaan dan lingkungan masyarakat, maka kebijakan pengaturan menjadi lebih tepat dan efektif didalam memenuhi keperluan dan kebutuhan masyarakat. Pemisahan kewenangan pemerintah pusat serta daerah di dalam penyelenggaraan wilayah laut serta maritim, terutama kewenangan pemerintah pusat di wilayah laut, bertujuan untuk meningkatkan kemampuan pertahanan laut khususnya pada wilayah perbatasan. Pemerintah daerah dengan melaksanakan berbagai kegiatan pembangunan yang andal, berjangka panjang,dan inklusif yang difokuskan pada kapasitas permodalan daerah, aspek kemasyarakatan, dan pemasaran.

Pemerintah pusat serta daerah bertanggung jawab memanfaatkan serta menjaga sumber wilayah daya pinggir laut serta pulau kecil. Penjagaan ketahanan dan keamanan laut merupakan tanggung jawab pemerintah pusat. Pengendalian wilayah laut yang mencakup bidang transportasi, pelayaran, pelabuhan serta perikanan adalah tanggung jawab pemerintah daerah. Pengelolaan wilayah pinggiran atau tepi serta pulau kecil dikelola serta dimanfaatkan oleh otoritas pusat dan otoritas daerah bersama dengan kewenangannya masing-masing. Tugas pemerintah pusat yaitu menjamin ketahanan dan stabilitas kawasan laut, sedangkan pemerintah daerah akan menguasai kawasan maritim di bidang transportasi, perikanan, pelabuhan, penyediaan air, dan perikanan.

\section{KESIMPULAN DAN SARAN}

\section{Kesimpulan}

Sesuai dengan penjelasan yang telah dijabarkan dalam pembahasan sebelumnya,jadi penulis bisa menarik kesimpulan yaitu:

1. Pengaturan Pembinaan Terhadap Persyaratan pengamanan keselamatan transportasi di wilayah perairan dapat disimpulkan bahwa pengaturan pembinaan negara memiliki kendali penuh atas perkapalan, serta pelaksanaan negara dilaksanakan oleh pemerintah terhadap pembinaan serta juga pelaksanaan negara. Regulasi, pemantauan, dan pengawasan adalah mekanisme yang digunakan pemerintah untuk memberikan pedoman. Bentuk pembinaan yang dilaksanakan oleh pemerintah yaitu berupa pengawasan, pengendalian, serta pengaturan. Syahbandar merupakan pejabat pemerintah yang menjalankan tugas pengarnanan keselamatan pelayaran. Dalam menjalankan tugas pengamanan keselamatan pelayaran yang berupa penyelenggaraan, pengawasan, penegakkan hukum di bidang transportasi air, pelabuhan, serta perlindungan wilayah laut di pelabuhan. menjalankan tugas pengamanan keselamatan pelayaran. Dalam menjalankan rugas pengamanan keselarnatan pelayaran yang berupa penyelenggaraan, pengawasan, penegakkan hukum di bidang transportasi air, pelabuhan, serta perlindungan wilayah laut di pelabuhan.

2. Kewenangan antara pemerintah pusat, pemerintah provinsi, dan bupati atau perkotaan, khususnya dibidang dinas wilayah laut serta perikanan yang telah ditentukan dalam peraturan perundang-undangan, tanpa menghibahkan tugas pemanfaatan kepada bupati 
atau daerah perkotaan kepada pemerintah pusat dan provinsi. Dengan asumsikewenangan yang diberikan hanya kepada pemerintah provinsi, hal ini bertentangan dengan tujuan memberikan otonomi seluas-luasnya kepada pemerintah daerah. Bahkan, muatan penting otonomi atau keadi Ian daerah yaitu penyerahan atau memberikan ghibah kewenangan pada penguasa pusat untuk penguasa daerah adalah desentralisasi politik serta ekonomi untuk peningkatan serta kemajuan perekonomian di bidang sumber daya alam dapat berlangsung secara adil dan merata di daerah.

\section{Saran}

Melalui penelitian ini penulis ingin menyampaikan beberapa saran yang kiranya dapat membantu dalam menguatkan peraturan pemerintah disektor pelayaran, yaitu:

1. Kepada pemerintah mengenai penguatan fungsi pengawasan perlu ditingkatkan di sektor pelayaran yang nantinya dapat mewujudkan sektor keselamatan bagi masyarakat yang menggunakan rransportasi angkutan laut. Terkait keselamatan pelayaran, perlu dilakukan pengelolaan secara menyeluruh terhadap pelaksanaannya.

2. Kepada masyarakat, dalam rangka optimalisasi peningkatan operasional pelayaran, masyarakat memiliki hak yang sama serta sebesar-besarnya untuk ikut serta di dalam kegiatan pelayaran. Masyarakat diharapkan dapat menawarkan bantuan finansial dalam pembuatan serta pelaksanaan program pendidikan serta training di daiam bidang industri perkapalan. Dalam konteks promosi, penegakan, dan penjagaan pelayaran, keterlibatan peran serta masyarakat dapat berupa pemberian informasi atau masukan terhadap pemerintah dan dewan daerah.

3. Kepada syahbandar dalam keselamatan pelayaran begitu penting karena peran tanggung jawab serta kewenangannya begitu vital atau penting. Begitu pentingnya peran tanggung jawab Syahbandar di dalam suatu pelabuhan adalah guna menopang disiplinnya serta sistematisnya pelaksanaan transportasi air serta keselamatan pelayaran, oleh karena itu peran, fungsi dan tanggung jawab tersebut mesti dibantu atau didorong oleh SOM yang memiliki keahlian, ketaatan, ketertiban, disiplin serta kemampuan, kompetensi, keterampilan, kualitas, keandalan dan kecakapan di sektor wilayah perairan. Perlengkapan alat yang menunjang juga sangat dibutuhkan agar tu gas dan fungsi dari syahbandar dapat maksirnal. Diperlukan peningkatan kompetensi dari petugas atau pegawai pelabuhan sehingga dapat meningkatkan perannya dalam menunjang keselamatan dan keamanan pelayaran.

\section{DAFTAR BACAAN}

Atmosudirdjo, S. P. (1981). Hukum Administrasi Negara. Ghalia Indonesia, Jakarta.

Djohan, A. (2008). Hukum Laut: Suatu Pengantar (Cet.1). Harvarindo.Jakarta.

Hamdi, M. F. (2016). Kewenangan Pemerintah terhadap Keselamatan dan Keamanan Perairan Indonesia. Jurnal Hukum Samudra Keadilan, Vol.11(1).

Hutagalung, S. M. (2017). Penetapan Alur Laut Kepulauan Indonesia (ALKI): Manfaatnya Dan Ancaman Bagi Keamananpelayarandi Wilayah Perairan Indonesia. Jurnal Asia Pacific Studies, Vol.1(1).

Kadarisman, M. (2017). Kebijakan Keselamatan dan Keamanan Maritim dalam Menunjang Sistem Transportasi Laut. Jurnal Manajemen Transportasi Dan Logistik, Vol. 4(2).

Munir, F. (2009). Teori negara hukum modern (rechtstaat). Refika Aditama, Bandung.

Nono, M. A. K. S., Wijaya, I. K. K. A \& Suryani, L. P. (2020). Pengawasan Pemerintah Daerah terhadap Usaha Pertambangan Galian C di Kabupaten Ngada. Jurnal Interpretasi Hukum, Vol.1(2).

Ridwan, H. (2006). Hukum Administrasi Negara. Raja Grafindo Persada, Jakarta.

Roesli, Roesdi. 1988, Peranan Pertahanan Keamanan Dalam Strategi Pengembangan Kelautan Di Indonesia Bagian Timur Serta Strategi Kelautan Pengembangan Kelautan Dalam Perspektif Pembangunan Nasional, Pustaka Sinar Harapan, Jakarta.

Sembiring, S. (2009). Pelayaran: Undang-Undang Republik Indonesia Nomor 17 Tahun 2008. CV Nuansa Aulia, Bandung.

Umar, M. H. (2001). Hukum maritim dan masalah-masalah pelayaran di Indonesia. Pustaka Sinar Harapan, Jakarta.

Susanti, Dyah, O. \& Efendi, A. (2014). Penelitian Hukum (Legal Research). Sinar Grafika, Jakarta. 